\title{
The Impact of Death of the Accused on the Criminal Action in the Jordanian Law
}

\author{
Hamzeh M. Abu Issa \\ Faculty of Law \\ Applied Science Private University (ASU) \\ Jordan \\ Abdallah Al-Khseilat \\ Faculty of Law \\ Middle East University (MEU) \\ Jordan
}

\begin{abstract}
The objective of this study is to clarify the legal provisions of the impact of the death of the accused on the criminal case according to the Jordanian Criminal Procedure Law. The research reviewed these provisions and the impact of death on the lawsuit, whether it was a public action or a personal action, as well as the impact of death on the penalty. The study also dealt with several legal problems on this subject such as the impact of mistake or ignorance of death and its consequences.
\end{abstract}

Keywords: Accused Death, criminal procedure, public action, civil action, Jordanian Law.

\section{Introduction:}

In the past, it was possible to bring proceedings against the corpse of the accused or his memory in some political crimes such as treason, and in some religious crimes, and suicide. ${ }^{1}$ This is no longer possible in the modern era where the criminal action dismissed upon the death of the accused. ${ }^{2}$ The reason for this lies in two things:

1- The principle of the personality of the case, which is linked to the principles of personality of the criminal liability and the personality of the punishment. If the liability and the penalty are personal, the case shall be so, as well, because it arises from the liability and is aimed at imposing the penalty. If it is recognized that the penalty will not achieve any of its purposes unless it is executed on a particular person who is responsible for the crime, the death of that person shall make it impossible to execute the penalty and to achieve its purposes. ${ }^{3}$ On this basis, the French jurisprudence ${ }^{4}$ says that upon the death of the defendant, the case loses its subject because the penalty is no longer feasible or logical. ${ }^{5}$

${ }^{1}$ Mohammed Al-Fadel, The Brief in the Principles of Criminal Proceedings, vol 1 ( $4^{\text {th }}$ edition, University of Damascus 1976) 140.

${ }^{2}$ Death means that the body has stopped performing all its vital functions permanently. It is considered a legal fact. Nabeel Medhat Salem, Explanation of the Criminal Procedure law, vol I (Dar al-Nahda al-Arabiya, Cairo 2009$) 443$.

${ }^{3}$ Mahmoud Najeeb Hosni, Explanation of the Criminal Procedure law ( $3{ }^{\text {rd }}$ edition, Dar al-Nahda al-Arabiya, Cairo 1995) 198. The Jordanian Court of Cassation states the following: (the legislator made the death of the complainant a reason for extinguishing the public claim. The reason behind this is that the criminal liability is considered a (personal liability), thus only the perpetrators of the crime can be held accountable. If the offender died the liability shall extinguish as the deceased doesn't have the capacity to bear such liability. Judgment of the court of cassation no. 956/2005 Dated 5/9/2005 Qistas Publications.

${ }^{4}$ Jh Lefort, Cours élémentaire de droit criminal (Ernest Thorin, Paris 1877) 306.

5 According to the Egyptian Court of Cassation, it is one of the basic principles that "no bearer of burdens will bear the burden of another", thus the penalties are purely personal and can only be executed on the person that is determined by the judiciary. The idea of this principle is that criminality does not entail surrogacy in prosecution and that does not entail surrogacy in the implementation. If a person dies and his personality is erased from the existence and his work is cut off from this world, his personal obligations shall be extinguished. If before the death he was an offender, his crime shall be deleted. If he was a convict, his penalty shall be extinguished. Gundi AbdulMalik, Criminal Encyclopedia (vol 3, Dar Ehya'a altorath alarabi, 1932)585. 
2- The death of the accused means that the case has lost one of its parties, thus taking any action against him in the time where it is impossible for him to discuss and defend himself makes no sense. ${ }^{6}$ No penalty shall be imposed without a trial in which the accused defense is heard. ${ }^{7}$

Accordingly, Article 336/1 of the Criminal Procedure Law provides that: "The public claim and the penalty shall be extinguished, whether in terms of the application of the original penalty or the additional or subsidiary penalty, upon the death of the accused".

The provision of this article applies not only to the death of the natural person, but also to the legal person, as the personality of a corporate can be extinguished. This extinguishment is seen by the virtue of death, thus the public claims extinguishes if the personality of the legal person has extinguished. In this regard, the Court of Cassation decided that: (The criminal action is extinguished from the partnership company upon cancellation of its registration, subject to the approval of all partners to dissolve or merge it with another company) ${ }^{8}$. In another decision, the court stated that: ((MS) company has been liquidated and the acts of its liquidation have been ended, which therefore ends its legal personality and makes it non justiciable. Since the criminal action extinguishes upon the death of the accused, it is not permissible to prosecute the company whose personality has extinguished). ${ }^{9}$

\section{The Provisions of Extinguishing the Criminal Action In Case Of the Death of an Accused:}

1- If the death occurred prior to the initiation of the action, the Public Prosecution shall not initiate it due to the impossibility of doing so. In such case, Prosecution shall issue a decision to extinguish the action pursuant to Article 130 of the Criminal Procedure law. ${ }^{10}$ Therefore, the Public Prosecution may not refer the case to the Court if it finds that the accused is dead. ${ }^{11}$

2- If the case was brought before the court, then the accused died during the hearing, the court shall stop the proceedings and extinguish it. The court may not render an acquittal in the case, even if there is insufficient evidence to convict. ${ }^{12}$ Also, it is not permissible to continue the hearing of the case regardless of any other reasons. ${ }^{13}$

${ }^{6}$ Ali Al-Kahwaji, Explanation of Criminal Procedure law, vol 1 (Al Halabi legal Publications, Beirut 2002) 261.

${ }^{7}$ The case is extinguish when the defense can no longer be heard. If there is no accused, there shall be no charge. Jh Lefort, Cours élémentaire de droit criminal (Ernest Thorin, Paris 1877) 306.

${ }^{8}$ Judgment of the court of cassation no. 25/2014 Dated 25/8/2014 Qistas Publications.

9 Judgment of the court of cassation 177/2016 Dated 24/10/2016 Qistas Publications.

${ }^{10}$ Article 130 (a) of the Penal law stipulates that: "If the Prosecutor finds that the act does not constitute an offense, or that there is no evidence that the defendant had committed the offense, or that the offense had been extinguished by death or time barred or pardoned. In the first and second cases, the prosecution of the defendant is prevented. In the other cases, the public claim shall be extinguished and the case file shall be send immediately to the director of the public prosecution.

${ }^{11}$ The Court of Cassation decided that: (According to the police documents that were referred to the director of the public prosecution, these documents were referred to director of the public prosecution at the time where Fares was dead and according to Article 335 of the Criminal Procedure Law, the public claim should have been extinguished by the death of the complainant. The director of the public prosecution should have dealt with the case in accordance with Article 17 of the Criminal Procedure Law, which ordered the director of the public prosecution to investigate the crimes and track the perpetrators, not to refer them to the criminal court to hear the case. He should have applied the provisions of the Article 335 of the Criminal Procedure Law by extinguishing the public claim due to the death of the complainant, but he did not do so). Judgment of the court of cassation no. 195/2005 Dated 16/3 /2005 Qistas Publications. The jurisprudence sees that if the public prosecution did not check the death of the complainant and the case was referred, the procedure of bringing it to court shall be void and the court shall have no competence to hear the case. Thus the court should have ruled the inadmissibility of the case due its extinguishment by the death of the complainant. Mohamed Zaki Abu Amer, Criminal procedures (Dar elgamaa elgadida, Alexandria 2005) 381.

${ }_{12}$ Judgment of the court of cassation no. 956/2005 Dated 5/9/2005, \& no.563/2010 dated 2/8/2010 Qistas Publications, which stated: (we found that the Court of Appeal had committed a legal mistake by deciding in its contested decision to declare the innocence of the deceased (Soliman). The mistake is that the accused had died during the trial and the court had decided to extinguish the public claim pursuant to article 336 of the Criminal Procedure Law, thus the decision to declare his innocence is unfounded and issued in an extinguished case that does not exist).

${ }^{13}$ Judgment of the court of cassation no. 195/2005 Dated 16/3/2005, Qistas Publications stated that:

As the documents were referred to the Juvenile Court and the judge found that the complainant was deceased, he had to issue the decision at the same hearing in which he received the documents and decide to extinguish the public rights case as hearing the case constitutes a gross error because he is prohibited from prosecuting the complainant due to his death and thus prevented from hearing the case. The claim of the claimant, which is to continue hearing the witnesses and to bring the medical report that determines the cause of the death of the complainant, is unfounded and contradicts with the public policy as long as the complainant's death is proven by an official death certificate issued by the Civil Status Department. 
3- If the accused died after the issuance of the judgment and the judgment was subject to appeal, that is, the death will take a place during the period of the appeal and before the judgment becomes final. According to the jurisprudence, ${ }^{14}$ this judgment shall be canceled and considered to be null and void because the case has been extinguished by the death, and it is not permissible for the public prosecution or the heirs ${ }^{15}$ to appeal this judgment.

4- If the accused dies after the submission of an appeal and during the legal period of the appeal - whether the appeal is submitted by him or the Public Prosecution - the competent court - if it is a trial court - shall issue a decision terminating the case due to the death.

5- If the death occurs after the case has been brought before the Court of Cassation ${ }^{16}$, the Court of Cassation cannot extinguish the case, but shall revoke the decision and return the papers to the trial Court so that it can render its decision. The Court of Cassation therefore stated that: "we found that the wife of the accused has submitted to our court a claim attached to a death certificate issued by the secretary of the civil registry office in West Amman stating that the accused had died and was included in the file of the case ... and since the public claim and the penalty extinguishes upon the death of the complainant ... according to Article (336/1)of the penal law....The judgment rendered in the case which is the subject of the appeal is not final, thus, the documents should be returned to the Court of Appeal accompanied by the death certificate of the appellant to verify its validity and apply its effect on the case". 17

\section{Death Is A Personal Extinguishment Cause:}

Death is one of the personal reasons of the extinguishment of the criminal case. In other words, if there are more than one accused and one of them died, the case will be extinguished relative to the deceased only without the other accomplices. This is what was confirmed by the Jordanian Court of Cassation stating that: (If the deceased is a partner in the crime and the principal offender with a number of the accomplices, the effect of death in this case shall be limited to the deceased only. It shall have no effect on the others). ${ }^{18}$ However, it is important to highlight that this rule is not absolute, as there is an exception in some crimes such as the crime of adultery. According to the preponderant view of the jurisprudence, the case is extinguished for the surviving partner in the crime of adultery. ${ }^{19}$ This is justified by the fact that according to the rule that both of them are innocent until a final conviction has been rendered. Thus if an accused dies before that, his partner shall benefit from this presumption of innocence. ${ }^{20}$ This view is consistent with article 284 of the Penal Law that stipulates that the fornicator and the fornicatress must be prosecuted together. ${ }^{21}$

${ }^{14}$ Mohamed Said Namour, The Rules of Criminal Procedures (Dar Al-Thaqafa, Amman 2005) 266.

${ }^{15}$ It is not permissible for the heirs or the relatives to invoke the moral interest to request the annulment of a judgment handed down against their decedent. Mahmoud Mahmoud Mustafa, Explanation of the Criminal Procedure Law (12 $2^{\text {th }}$ edition, Cairo University 1988) 130.

${ }^{16}$ The death is proved according to the Civil Status Law. The Jordanian Court of Cassation stated the following: (Since the civil registry offices have the authority to register the families of Jordanians in the civil registry and to register the events, and to issue the relevant certificates. These records and the copies made from them are valid unless proven otherwise or invalidated by a judicial decision. The criminal Court of appeal should have confirmed the death of the accused through the Civil Status Service). The decision concluded that the death must be verified according to the legal rules stipulated in the Civil Status Law. Judgment of the court of cassation no. 223/1987 dated 7/10/1987 Qistas Publications.

${ }^{17}$ Judgment of the court of cassation no. 215/2010 dated 30/3/2010 Qistas Publications. In another decision, it said: "Since the judgment in this case is not final and our court decided to overturn the contested decision, the copy of the death certificate of the defendant must be returned to the Court of Appeal to verify its validity and apply its effect on the case." Judgment of the court of cassation no. 2018/2011 dated 24/1/2011 Qistas Publications. The Court of Cassation appears to have departed from this rule in its decision No. 741/2015 dated 13/8/2015, where it extinguished the case without returning it to the trial court. The decision stated that: (We find that the lawyer Ahmad Najdawi on 1/6/2015 has submitted a claim to the court indicating that his client has moved to the mercy of God on 26/5/2015 and attached his claim with a certificate issued by the civil status dated 31 May 2015. Accordingly, we see that article 336 of the Penal Law had stipulated that if the complainant has died, the public claim and the penalty shall be extinguished. Therefore, based on the above, we decide to overturn the contested judgment and to extinguish the public claim due to the death of the convict.

${ }^{18}$ Judgment of the court of cassation no. 965/2005 (noted above).

${ }^{19}$ Hatem Madi, Criminal Procedure Law ( $3^{\text {rd }}$ edition, Zain Legal Publications, Beirut 2016) 104.

${ }^{20}$ Ra'uf Obeid, Principles of Criminal Procedure in Egyptian Law (Dar Al-Fikr Al-Arabi, Cairo 2005) 138.

${ }^{21}$ Article 284/4 of the Penal Law, prior to its amendment, provides that: (if the husband returned his wife or if the husband, the complainant, the fornicatress or her partner in adultery has died, the complaint will be extinguished). This judgment was subsequently repealed by the amended Act No. 86 of 2001. Some have argued that such repeal means that the death of one of the adulterers does not prevent the prosecution of the other. Abdul Wahab Al-Batrawi, Explanation of the Criminal 


\section{The Impact of the Death on the Penalty}

It is well established that the penalty shall be extinguished upon the death of the convict if he dies after the conviction has become final, as the penalty can no longer be imposed whatever its kind is. This is stated in Article 49 of the Penal Law: "1. All the criminal consequences of the judgment shall be removed by the death of the convict. 2. Death prevents the payment of fines and fees. 3. The death shall have no effect on the in-rem confiscation and on the closure of the premises".

Thus, it is noted that death prevents the payment of fines and fees, based on the fact that the fine is considered a penalty that is aimed at deterring the convicted person so as not to return to the crime. This is related to the state of life, thus if he dies, the deterrence shall not be achieved and it is not permissible to take the fine from his legacy. ${ }^{22}$

As for the confiscation, the previous article clarified that the death does not affect the in-rem confiscation. Article (36612) of the Criminal Procedure Law states that: "if the seized items are legally prohibited, they shall not be returned to the heirs of the deceased." According to these texts, a distinction must be drawn between the compulsory confiscation (in rem) which is a precautionary measure and the discretionary confiscation, which is considered as an accessory penalty. Death does not affect the first type, but it prevents the execution of the second type. ${ }^{23}$ Therefore, the court may decide to confiscate the seized items, which their seizure, usage, possession, selling or offering for sale is, in itself, a crime, despite death. The reason for this is that the in-rem confiscation is not a penalty or a personal measure. It is not a judgment rendered against a dead person, but a precautionary measure that affects the objects not the persons. Confiscation applies only on what is legally prohibited. ${ }^{24}$

\section{The Impact of Death on the Civil Action:}

In civil trials, if one of the parties dies, the court shall inform one of his heirs mentioned in the civil registration. The heirs shall be informed without mentioning their names and statuses in the last domicile of the deceased through publishing in two local daily newspapers (Article 12313 of the civil procedure). This means that the civil action continues after death. Does this apply to the civil claim in the criminal case (the personal claim)?

It is well established that the public claim extinguishes upon death, as we have already pointed out, thus there is no reason to apply the text of Article 123 of the Civil Procedure Law, which applies to civil cases subject to its provisions. ${ }^{25}$ As for the personal claim, Article (36613) of the Criminal Procedure Law stipulates that: "The injured party shall have the right to bring a personal action before the court and to claim compensation from the heirs of the deceased". According to this text, it is clear that the right to compensation does not extinguish, but that the victim must claim it before the competent civil court. This means that the personal claim does not continue before the criminal court.

It is not permissible for the court to inform the heirs and to proceed with the personal claim or the compensation, but this is done by bringing a fresh case before the civil courts due to the explicitness of the text of the article (36613). ${ }^{26}$ From the above, it turns out that in the case of the death of the accused in a criminal case, the case shall be extinguished by death and the personal claim shall be within the jurisdiction of the civil court. As long as the personal claim follows the criminal case, the procedures stipulated in the Civil Procedure Law are not applied to the personal claim of the criminal case and, therefore, there is no reason to inform the heirs of the deceased in the criminal case. Consequently, in the case of death, the criminal court that hears the personal claim of the criminal case shall not be competent to hear the personal claim and it must dismiss the case for the lack of jurisdiction. ${ }^{27}$

Procedure Law (Applied Science University, Bahrain 2007) 40. We do not support this view as the text is clear in prosecuting the fornicator and fornicatress together.

${ }_{22}^{22}$ Mohammed Al- Zuhayli, Sharian Criminal Procedures, vol I (Dar Al-Fekr, Damascus, 2015) 94.

${ }^{23}$ Ra'uf Obeid, Principles of Criminal Procedure in Egyptian Law (Dar Al-Fikr Al-Arabi, Cairo 2005) 136.

${ }^{24}$ Judgment of the court of cassation no. 965/2005 dated 5/9/2005 (noted above).

${ }^{25}$ Judgment of the court of cassation no. 1021/2011 dated 6/9/2011 Qistas Publications

${ }^{26}$ Judgment of the court of cassation no.1979/2009 dated 11/4/2010 Qistas Publications, and Judgment of the court of cassation no. 755/2016 dated 4/7/2016 which stated: (since the case is a criminal case and (S) has died during the course of the proceedings, the provisions of Article 336 shall be applicable because there is no provision in the Customs Law that is contrary to the provision of this article. The Chamber shall have the right to prosecute the heirs of the deceased for the fines, which is civil compensation before the civil court in accordance with the provisions of article 366/3 of the same law.

27 Judgment of the court of appeal of Amman no. 32335/2013 dated 3/11/2013 Qistas Publications; and the judgment of the court of the appeal of Amman no. 20774/2013 dated 3/7/2013 which states: "By reviewing the third paragraph of article 336 of the penal law, we find that the legislator has limited the right to bring the personal claim of the injured before the 134 


\section{Mistake or Ignorance of Death:}

The court may extinguish the public claim upon death and then it turns out that the accused is still alive, or the court may render a judgment against a person and then finds out that the person was dead when the sentence was rendered. What is the way to rectify such mistakes?

As for the first assumption, that is, if the case was extinguished because of death and found out then that the accused was still alive, the mistake shall be considered a mistake of fact which could be rectified by appealing the judgment if the appeal was available. ${ }^{28}$ However, the problem may arise when the judgment becomes final, in this case we find that the jurists have disagreed on that. Some of them - influenced by the Egyptian Court of Cassation - see this mistake as a material mistake that can be corrected by recoursing back to the same court that issued it to correct its mistake. ${ }^{29}$ This view can be criticized on the grounds that the mistake of the court, in this case, cannot be considered as a material mistake, since the material mistake is a mistake in writing or expression which does not affect the creed of the judge, and that the mistake of the judge is a mistake of establishing his creed. ${ }^{30}$

According to another view, if such judgment became final and could not be appealed, there shall be no ground to take any action up against. ${ }^{31} \mathrm{We}$ see that this view may not achieve justice in terms of the impunity of the offender for an intentional mistake of the Court.

The view that we believe to be valid is that this judgment, since it does not settle the subject matter, does not acquire the power to prevent the case from being reviewed, but rather it could be brought before the competent court again. ${ }^{32}$ The judgment that becomes res judicata is the judgment that settles the subject matter and the judgment of extinguishing the case for the death of the complainant is not from this judgment. ${ }^{33}$

As for the second assumption, which is rendering a judgment against a person who has died without the court being aware of his death, it is established that the criminal case extinguishes by the force of law upon the death of the accused. Thus, the judgment issued after the death - whether or not the court was aware of it - is null and void because the criminal case has been extinguished by the force law from the moment of death. On this basis, this judgment becomes null and void, and shall not have any executive effect. The convict becomes innocent by the force of law from the moment of his death before the judgment has been rendered against him. As long as this is the case, it is not permissible to appeal this judgment in any way because it is null and void. ${ }^{34}$ This judgment shall not become res judicata and shall not have any binding force before the civil court. ${ }^{35}$ This is what was decided by the Jordanian Court of Cassation, where it says: "If the court rendered a judgment in the case despite the death without being aware of it, this judgment shall be null and void, and shall have no binding force." ${ }^{36}$

\section{Conclusion}

We presented in this research one of the general reasons for the expiration of a criminal case, 'namely the death of the accused'. It was found that this is a personal reason that only the deceased person benefits from except with regard to the crime of adultery, where the partner as well shall benefit from this reason: 'the death of his partner' because the prosecution in this crime shall be done for both. The death of the accused shall result to extinguish the lawsuit.

civil courts against the heirs. Since the Court of First Instance has dismissed the claim due to the lack of jurisdiction, it has applied the law correctly).

${ }^{28}$ Soliman Abdel Moneim, The Rules of Criminal Procedure, vol 1 (Al-Halabi legal Publications, Beirut 2003) 478.

${ }^{29}$ Ahmed Fathi Sorour, El Wasit in the Criminal Procedure Law, vol 1 (Dar alnahda alarbiya, Cairo 2014) 278.

${ }^{30}$ Ali Al-Kahwaji, Explanation of Criminal Procedure law, vol 1 (Al Halabi legal Publications, Beirut 2002) 268. Some say that: "Saying that the judgment of extinguishing the case upon death that is rendered before the accused appears to be alive is a material mistake means the recognition of the bases of this judgment. This is contrary to the reality, since the subject matter of the criminal case is not yet settled, and then the pen mistakes. Thus there is no mistake in expressing the will of the court. Mustafa Mohamed Abdel Mohsen, the Extinguishment of the Criminal Case - Alternatives and Assumptions (Dar alnahda alarbiya, Cairo 2003/2004) 296.

${ }^{31}$ Hassan Sadiq Al-Marsafawi, Al-Marsafawi in the Rules of Criminal Procedures (Dar Al Maaref, Alexandria, 1996) 181.

${ }^{32}$ Awad Mohammed Awad, General Principles of the Criminal Procedure Law,(Dar Al Maaref, Alexandria) 105.

${ }^{33}$ Ali Al-Kahwaji, Explanation of Criminal Procedure law, vol 1 (Al Halabi legal Publications, Beirut 2002) 269, Although he sees that the judgment could be reviewed by the same court that had issued it in order to continue its hearing and to render the judgment on its merits.

${ }_{35}^{34}$ Mohamed Zaki Abu Amer, Criminal procedures (Dar elgamaa elgadida, Alexandria 2005) 384.

35 Ahmed Fathi Sorour, El Wasit in the Criminal Procedure Law, vol 1 (Dar alnahda alarbiya, Cairo 2014) 277.

${ }^{36}$ Judgment of the court of cassation no. 965/2005 dated 5/9/2005 (noted above). 
Hence if the case where under the possession of the public prosecution, it must issue a decision to extinguish the case, however if the death occurred during the trial and before the verdict, the court should extinguish the case without completing the case.

Moreover, if the effect of death relates to extinguish of the public right, then this effect shall also extend to the claim of personal right, where the Criminal Court should not continue to consider this case against the heirs, while the victim must bring his case before the civil courts. Since the death extinguish all of the penalties imposed except for confiscation in kind. The research clarifies solutions to the problem of mistake or ignorance of death, where if the court mistakenly extinguished the case against the accused for his death and then it found that he still alive, the common opinion for this situation is to re-suit the accused again since the previous judgment did not rule on the subject of the case. Nevertheless, if the court made a mistake by passing judgment on a deceased person without knowing that, then it is certain that this judgment is null and does not have any effect.

\section{Acknowledgements}

The authors would like to thanks Applied Science Private University/ Jordan for its support of this research. 